\title{
Kadar Konsep Diri Mahasiswa Dalam Berinteraksi Di Media Sosial
}

\author{
Vera Wijayanti Sutjipto ${ }^{1 *}$, Rayni Delya Hafni ${ }^{2}$ \\ ${ }^{1}$ Program Studi Ilmu Komunikasi, Universitas Negeri Jakarta, Jakarta, Indonesia \\ 2 Program Studi Ilmu Komunikasi, Universitas Negeri Jakarta, Jakarta, Indonesia \\ *e-mail: verawijayanti@unj.ac.id
}

Article history: Received 28 July 2020; Accepted 19 August 2020; Available online 31 August 2020

\begin{abstract}
Abstrak
Penelitian ini bertujuan untuk meninjau kadar konsep diri mahasiswa dalam berinteraksi di media sosial. Adapun peneliti menggunakan metode penelitian kuantitatif deskriptif dengan menyebarkan kuesioner pada 80 orang mahasiswa UNJ Angkatan 2019 dari 8 fakultas yang ada di UNJ. Hasil dari penelitian ini yaitu konsep diri mahasiswa ketika berinteraksi di media sosial menunjukkan sangat kuat dengan mereka lebih suka menghindar konflik, tidak berkomentar negatif mengenai postingan orang lain, tetapi terdapat juga mahasiswa yang mudah terprofokasi oleh postingan orang lain di media sosial. Hal ini menunjukkan ketika mereka berinterkasi dengan orang lain seringkali mudah terpengaruh, ini disebabkan oleh konsep diri yang masih berubah-ubah, salah satunya karena pengaruh lingkungan. Oleh sebab itu mahasiswa sebagai remaja harus menyadari bahwa konsep diri mereka bisa berubah ketika berinterkasi di dunia maya, dengan berbagai sebab seperti tidak melihat langsung ekspresi lawan bicara.
\end{abstract}

\begin{abstract}
This study aims to review the levels of students' self-concept in the social media category. The researchers used a descriptive quantitative research method with a questionnaire on 80 UNJ Class 2019 students from 8 faculties at UNJ. The result of this research is that students' self-concept, if it can be read on social media, shows that it is very strong with them preferring to avoid conflict, not making negative comments about other people's posts, but there are also students who are easily profiled by other people's posts on social media. This shows that when they interact with other close people easily, this is due to the changing self-concept, one of which is due to environmental influences. Therefore, students as teenagers must be aware that their self-concept can change when interacting in cyberspace, for various reasons such as not seeing expressions of speech expression.
\end{abstract}

Kata Kunci:

Interaksi; Konsep Diri; Mahasiswa; Media Sosial

Keywords:

Interaction; Selfconcept; Students; Social Media

Copyright (c) Universitas Pendidikan Ganesha. All rights reserved.

\section{Pendahuluan}

Berdasarkan hasil survei yang dilakukan oleh TNS, sebuah perusahaan market research di Indonesia, menyatakan bahwa remaja adalah pengguna internet terbanyak di Indonesia (Tribunnews.com, 2016). Menurut World Health Organization (WHO) kategori umur remaja berada antara umur 10 tahun - 19 tahun, namun berdasarkan Peraturan Menteri Kesehatan RI pada Nomor 25 tahun 2014, yang dikaterogrikan seorang remaja yaitu antara umur 10 tahun - 
18 tahun. Berbeda dengan Badan Kependudukan dan Keluarga Berencana (BKKBN) mengumumkan bahwa umur yang termasuk remaja itu antara 10 tahun-24 tahun.

Di Indonesia, dari 145 juta pengguna internet, 43,89\% adalah golongan remaja, dimana mereka menghabiskan waktunya rata-rata 1-3 jam per sehari dalam menggunakan internet, sekitar 29,63\% pengguna lainnya menghabiskan waktu mereka sekitar 4-7 jam sehari (Diah, 2018). Aplikasi di internet yang paling banyak mereka akses adalah aplikasi media sosial terutama Instagram(Katadata.com, 2018),

Perubahan teknologi yang cepat terutama internet membawa dampak pada kehidupan penggunanya, mahasiswa adalah salah satu kelompok remaja yang aktif mengakses internet terutama aplikasi media sosial, pasti merasakan dampak postitf dan negatif baik bagi dirinya ataupun bagi orang sekitarnya. Penelitian mengenai akibat dari media baru belumlah banyak dan dalam, seperti pada penelitian mengenai media lama, contohnya televisi atau koran.

Dampak media baru yang menonjol adalah dari sisi akses media baru. Pengguna bisa mengakses media baru setiap saat, hal ini berbeda dengan media lama seperti koran atau teleivisi. Kemudahan tersebut karena pengguna mempunyai alat akses berupa handphone pribadi yang membuat pengguna terkoneksi dengan mudahnya, akibatnya penggunanya tidak dapt mengendalikan diri untuk selalu mengakses media baru dimana saja dan kapan saja, disamping itu media baru tidak seperti media lama dari sisi pengawasannya, dimana perilaku pengguna media baru dikenal dengan konektivitas 24/7 dengan yang lain (Hogan \& Strasburger, 2018).

Perkembangan teknologi internet memaksa pengguna berubah, terutama perubahan dalam perilaku komunikasi dengan orang lain, perubahan juga terjadi pada nilai-nilai yang mereka pegang sebelumnya, seperti bagaimana menghormati ruang pribadi orang lain, bagaimana menyampaikan pendapat dengan baik dan santun. Mahasiswa yang di kategorikan sebagai anak muda menghabiskan sebagian waktunya untuk mengakses media sosial, ini bisa berdampak pada konsep diri mereka ketika berkomunikasi.

Internet, membawa perubahan pada konsep diri mahasiswa dengan temannya. Perubahan itu antara lain berupa perubahan dalam pengunaan simbol atau makna, dimana terdapat perbedaan makna dan simbol yang harus dipahami individu ketika berinteraksi. Perubahan cara interaksi tersebut, disebabkan karena salah dalam menggunakan simbol-simbol ketika berinterkasi di dunia maya, yang menyebabkan mahasiswa merasa menjadi orang lain ketika dia berkomunikasi di dunia maya, dia merasa lebih emosional dalam berkomunikasi, sehingga pernah terjadi argumen yang cukup hebat di media sosialnya. Tujuan penelitian ini, ingin mengetahui bagaimana konsep diri dikalangan anak muda, khususnya mahasiswa di Univeristas Negeri Jakarta melalui Media Sosial.

Hasil penelitian yang lalu dan mempunyai hubungan dengan penelitian ini sebagai berikut. Jurnal dengan judul Social Media and New Technology: A Primer. Penelitian ini ditulis oleh Marjorie Hogan dan Victor C Starburger (Hogan \& Strasburger, 2018). Jurnal ini mengulas mengenai penggunaan media sosial saat ini, baik dari sisi manfaat dan resikonya. Penelitian mengenai media sosial belumlah sebanyak penelitian mengenai media tradisional. Penggunaan media sosial ke depan akan makin banyak dan digemari, kemungkinan perubahaan hanya terjadi pada jenis platform yang digunakan dan digemari. Penelitian pada media tradisional seperti TV, film, video, koran, majalah dan sebagainya telah terbukti memiliki dampak terhadap pemirsanya, dimana sebagian besar dampaknya pada kesehatan dari pemirsanya seperti obsistas, lebih agresif, namun penelitian mengenai media baru masih dalam masa perkembangan. Remaja perlu memahami bagaimana menggunakan media sosial dengan aman dan orang tua perlu waspada dan mengenali platform media sosial yang digunakan oleh anakanak mereka.

Jurnal yang berjudul The social media see-saw: Positive and Negative Influences on Adolescents' Affective Well-Being, jurnal ini ditulis oleh Emily Weinstein (Weinstein, 2018). Jurnal ini mengulas mengenai penggunaan media sosial di kalangan remaja di Amerika. 
Bagaimana interaksi mereka sehari-hari dengan aplikasi di media sosial. Penelitian ini menyebarkan kuesioner pada 568 remaja Amerika. Analisis terhadap hasil penelitian menunjukkan bahwa emosi positif dan negatif membentuk wawancara mendalam dengan subsampel berjumlah 26 orang, dipilih untuk mengungkapkan pengalaman yang memengaruhi diatur oleh empat dimensi fungsional. Interaksi relasional berkontribusi pada kedekatan dan pemutusan; ekspresi diri memfasilitasi afirmasi bersama dengan keprihatinan tentang penilaian orang lain; eksplorasi yang didorong minat memberi inspirasi dan kesusahan; dan menjelajah mengarah pada hiburan dan kebosanan, serta kekaguman dan iri hati. Semua yang diwawancarai menggambarkan pengalaman terhadap pengaruh positif dan negatif dalam berbagai dimensi. Analisis menunjukkan hubungan antara penggunaan teknologi sosial dan kesejahteraan - apakah ditingkatkan atau diturunkan - tidak terbatas pada kerangka "baik / atau": penglihatan emosional penggunaan media sosial ditimbang oleh pengaruh positif dan negatif.

Jurnal dengan judul The Digital Hood: Social Media Use Among Youth in Disadvantaged Aeighborhoods, jurnal ini ditulis oleh Robin Stevens, Stacia Gilliard-Matthews, Jamie Dunaev Rutgers, Marcus K Woods dan Bridgette M Brawner(Stevens et al., 2017). Artikel ini mengenai peran media sosial dalam kehidupan kaum muda yang tinggal di lingkungan yang kurang beruntung. Teori Sudut Pandang Feminis, yang mengistimewakan suara masyarakat yang terpinggirkan dalam memahami fenomena sosial, menunjukkan bahwa kaum muda di pinggiran memiliki pengetahuan khusus yang membantu kita memahami media sosial secara lebih luas. Peneliti melakukan wawancara semi-terstruktur dengan 30 wanita dan 30 pria berumur 13-24 tahun tentang dunia sosial dan lingkungan mereka, baik online maupun offline. Temuan ini mengungkapkan interaksi yang dinamis dan agak mengkhawatirkan antara lingkungan geografis dan lingkungan digital, di mana interaksi sosial negatif di lingkungan geografis tersebut dan di dukung dengan adanya media sosial.

Konsep diri adalah bagaimana persepsi diri kita secara sosial, psikologi, dan fisis yang ada karena interaksi kita dan pengalaman dalam berinteraksi dengan orang lain. Hal ini merupakan persepsi seseorang akan dirinya sendiri, dimana dapat tebentuk melaui pengalaman dan pandangan atas dirinya sendiri. Adapun psikoanalitik dalam Agustini \& Arthana (2016) yang dikemukakan oleh Sigmud Freud tentang tiga elemen dari konsep diri yang terdapat pada individu, yaitu sebagai berikut. Pertama, Id merupakan bagian dari diri individu yang sudah ada seja ia lahir, hal ini dikenal sebagai naluri. Id ini akan membuat seseorang mengalami kecenderungan untuk membuat dirinya merasa senang dan berusaha untuk memenuhi keinginan dasarnya. Ketika kondisi mental memiliki tujuan agar seseorang dapat bertahan hidup ini disebut Id. Karena, ketika kebutuhan Id seseorang tidak terpenuhi, maka ia akan mengalami gelisah, cemas, marah, atau tengang. Kedua, ego adalah kondisi mental dari individu yang bekerja sesuai realita yang dihadapinya. Salah satu fungi ego adalah mengontrol Id yang bekerja secara naluri. Ego bekerja pada tataran pikiran individu ddalam kondisi pikirannya sadar maupun tidak sadar. Ketiga, superego merupakan kondisi mental individu, fungsinya sebagai penengah antara Id dan Ego. Superego bekerja sebagai penekan Id, jika Id lagi menguasai individu, dengan tekanan Superego tersebut maka Ego akan muncul agar individu berpikir secara realistis.

Konsep diri merupakan berbagai presepsi seseorang terhadap dirinya sendiri dan lingkungannya yang terbentuk dari hasil bagaimana seseorang beinterkasi dengan orang lain yang telah ia interpretasikan. Brooks menjelaskan dalam Agustini \& Arthana (2016), bahwa konsep diri itu bagaimana ia mempresepsikan dirinya sendiri, baik secara psikologis, sosial, maupun fisik yang ada berdasarkan dari pengalaman-pengalaman hasil ia berinteraksi dengan orang lain. Konsep diri hadir bukan hanya ada pada persepsi yang memiliki sifat deskriptif, tetapi juga karena penilaian yang hadir terhadap diri sendiri sebagai suatu keseluruhan persepsinya kepada aspek diri sendiri yang meliputi pada aspek sosial, psikologis dan aspek fisik, yang hadir berdasarkan melalui pengalaman serta interaksi individu dengan orang lain yang ada disekitarnya (Karmila, 2018). 
Hurlock dalam (Rizadan, 2019) menjelaskan jika konsep diri merupakan suatu presepsi seseorang kepada dirinya sendiri. Sedangkan Brook dalam (Rizadan, 2019) berpendapat bahwa konsep diri adalah cara pandang serta perasaan seseorang mengenai dirinya, lalu presepsi bagaimana diri dapat bersifat sosial, fisik, dan psikologi yang hadir melalui dari apa yang ia pikirkan serta rasakan mengenai dirinya sendiri. Hal ini kembali diperkuat bahwa konsep diri adalah suatu cara pandang seseorang yang menilai tentang dirinya (Yuniati, Yuningsih, \& Nurahmawati, 2015).

\section{Metode}

Dalam penelitian ini, peneliti menggunakan kuantitatif deskriptif, yaitu peneliti hanya melakukan penggambaran pada objek yang akan diteliti berdasarkan data yang didapatkan melalui penyebaran kuesioner. Selain itu, peneliti juga menggunakan data-data sekunder dengan melakukan wawancara, studi pustaka, dan juga melakukan telaah observasi virtual dengan menyimak komentar-komentar dan postingan di linimasa sosial media seperti Instagram, Twitter, dan Facebook milik responden. Populasi penelitian ini berjumlah 400 mahasiswa Angkatan 2019 yang aktif di Badan Eksekutif Mahasiswa yang berasal dari 8 fakultas. Berdasarkan perhitungan dengan memakai rumus slovin maka diperoleh jumlah sampel sebesar 80 mahasiswa.

Teknik penarikan sampel penelitian ini adalah sampel acak sederhana, dengan alasan populasi pada penelitian ini homogen dan jumlahnya tidak terlalu banyak. Selain pengumpulan data melalui kuesioner, penelitian ini menggunakan wawancara untuk data sekunder, dalam rangka mengali dan memperkaya informasi yang sudah diperoleh melalui penyebaran kuesioner sebelumnya. Pertanyaan wawancara berhubungan dengan informasi personal informan, termasuk kebiasaan dalam mengakses internet, pertanyaan lainnya mengenai, konsep diri mereka ketika berinteraksi melalui tatap muka ataupun lewat media sosial mereka.

Selain itu, peneliti melakukan pengujian validitas konstruksi dengan menggunakan skala interval yang dilakukan melalui hasil running SPSS 16.0. Berdasarkan hasil pengujian validitas variabel X pada penelitian ini, peneliti mendapatkan hasil nilai KMO yaitu 0.551 dan dengan ini menunjukkan lebih dari 0.5 (Malhotra, 2010), hal ini dapat dinyatakan bahwa variabel Konsep Diri (X) dinyatakan valid. Uji reliabilitas pada penelitian ini dilakukan dengan uji Metode Alpha Cronbach's. Hasilnya menunjukkan variabel X dalam penelitian ini, memperoleh nilai Cronbach's Alpha sebesar 0.707 yang melebihi 0.6 (Malhotra, 2010) sehingga nilai tersebut dapat diartikan jika variabel Konsep Diri (X) dinyatakan reliabel.

Skala yang digunakan adalah skala interval, sehingga penelitian ini memiliki ukuran tendensi sentral yaitu mean. Selain itu, peneliti ini menggunakan satu variabel yaitu konsep diri. Dalam variabel tersebut, terdapat tiga dimensi yaitu Id, Ego, dan Superego. Pada dimensi Id terdapat dua indikator yaitu indikator merasa senang dan indikator memenuhi keinginan dasarnya. Dimensi Ego memiliki dua indikator, yaitu kondisi pikiran sadar dan kondisi pikiran tidak sadar, dimensi terakhir yaitu Dimensi Superego memiliki satu indikator, yaitu penengah antara id dan ego.

\section{Hasil dan Pembahasan}

Penelitian ini dilakukan pada masa pandemic Covid-19, penyebaran kuesioner dan wawancara dilakukan melalui daring. Kuesioner yang dikembalikan dan diisi lengkap oleh 60 mahasiswa perempuan dan 20 mahasiswa laki-laki. Sebanyak 73 mahasiswa (91\%) mengaku mengakses media sosial setiap hari, 54 orang $(67,6 \%)$ mengakses media sosial mereka lebih dari 3 (tiga) jam sehari. Bahkan ada mahasiswa yang menghabiskan waktunya sampai 15 jam dalam sehari mengakakses media sosialnya. 
Sekitar 70 orang mahasiswa $(87,5 \%)$ menyatakan bahwa aktivitas selama mengakses media sosial lebih membaca postingan atau komen dari orang lain, mereka tidak selalu setiap hari memposting konten atau memberikan komentar, namun 10 mahasiswa $(12,5 \%)$ menyatakan bahwa ketika mereka mengakses media sosial, jika tidak memposting konten, mereka minimal memberikan komentar mengenai postingan orang lain.

Terdapat lebih dari satu aplikasi media sosial yang mereka gunakan, namun facebook adalah media sosial yang banyak dipakai mahasiswa karena facebook bagi mereka adalah media sosial yang pertama kali dikenal. Berdasarkan survei 78 orang mahasiswa $(97,8 \%)$ menyatakan bahwa mereka mempunyai follower lebih dari 50 akun, rata-rata mempunyi follower sekitar 500 akun, bahkan ada yang mempunyai lebih dari 1000 folower seperti Khalda, mahasiswa dari Fakultas Ilmu Sosial ini.

Sebagian besar dari mahasiswa ini mulai punya akun media sosial ketika mereka duduk di bangku sekolah dasar, tujuan awalnya ikut-ikutan teman sebaya yang sudah punya akun media sosial terlebih dahulu bahkan ada diantara mereka sudah punya akun ketika mereka masih berberumur 9 tahun. Beberapa alasan mereka mempunyai media sosial antara lain agar silaturahim diantara teman lama tetap terjalin, menambah teman baru, update berita atau gosip terbaru, bisa berkomunikasi cepat dengan biaya murah.

Berdasarkan hasil temuan peneliti, 64 orang ( $80 \%$ ) menilai diri mereka adalah orang yang ramah dan banyak teman. Sebagian besar dari mereka yaitu 55 orang $(68,7 \%)$ menilai diri mereka punya pendirian dan tidak mudah terpengaruh orang lain. Teman-teman mereka pun mempunyai penilaian yang sama terhadap mereka yaitu 56 orang (70\%). Ketika bergaul sesama teman mereka jarang terlibat konflik, jika pun ada konflik, bisa diselesaikan dengan baik. Mereka pun menyatakan bahwa dalam pergaulan mereka akan selalu bersifat sopan dan berpegang pada etika.

\section{Identitas (ID)}

Konsep diri seorang mahasiswa berpengaruh pada bagaimana cara mereka berinteraksi baik itu tatap muka atau melalui media sosial. Apakah dengan perubahan media interaksi tersebut, akan merubah konsep diri dari mahasiswa tersebut. Di bawah ini merupakan tabel hasil per pernyataan penelitian.

Tabel 1

Berperilaku Kehendak Diri di Media Sosial

\begin{tabular}{cccc}
\hline Declaration & Frequency & Percentage & Mean \\
\hline $4(\mathrm{SS})$ & 12 & $15 \%$ & \\
$3(\mathrm{~S})$ & 42 & $52,5 \%$ & \\
$2(\mathrm{KS})$ & 22 & $27,5 \%$ & 2,77 \\
1 (TS) & 4 & $5,0 \%$ & \\
\hline Total & 80 & $100,0 \%$ & \\
\hline
\end{tabular}

Pada tabel 1 terdapat 64 orang mahasiswa (67,5\%) menyatakan ketika mereka berinterkasi lewat media sosial, mereka akan berperilaku semau mereka, sedangkan 26 orang mahasiswa $(32,5 \%)$ menyatakan tidak berperilaku sekehendak mereka. Mahasiswa, yang bernama Shalsabilla, angkatan 2019 dari Fakultas Ilmu Pendidikan, menyatakan dia berperilaku sekehendak diri karena dia merasa tidak ada urusan kepada orang lain dan berharap orang lain juga tidak memedulikan dirinya, apalagi jika orang tersebut komentarnya negatif. 
Tabel 2

Populer Di Media Sosial

\begin{tabular}{cccc}
\hline Declaration & Frequency & Percentage & Mean \\
\hline 4 (SS) & 1 & $1,3 \%$ & \\
$3(\mathrm{~S})$ & 7 & $8,8 \%$ & \\
2 (KS) & 42 & $52,5 \%$ & 1,73 \\
1 (TS) & 30 & $37,5 \%$ & \\
\hline Total & 80 & $100,0 \%$ & \\
\hline
\end{tabular}

Tujuan mahasiswa UNJ menggunakan media sosial bukan untuk mencari popularitas. Sebanyak 72 orang mahasiswa $(90 \%)$ tidak ingin populer di media sosial, hanya 8 orang mahasiswa (10.1\%) yang ingin populer di media sosial. Mahasiswa, yang bernama Khalda, angkatan 2019 dari Fakultas Ilmu Sosial menyatakan bahwa ia merasa lebih nyaman memprivate akun media sosialnya karena ia merasa terganggu dengan pengguna yang menstalking akunnya secara berlebihan. Hal yang sama juga diungkapkan Shalsabilla, dimana dia merasa kurang nyaman bila setiap orang dapat melihat isi postingan dia di media sosial.

Tabel 3

Memposting Di Media Sosial

\begin{tabular}{cccc}
\hline Declaration & Frequency & Percentage & Mean \\
\hline $4(\mathrm{SS})$ & 16 & $20,0 \%$ & \\
$3(\mathrm{~S})$ & 50 & $62,5 \%$ & \\
$2(\mathrm{KS})$ & 11 & $13,8 \%$ & 2,98 \\
1 (TS) & 3 & $3,8 \%$ & \\
\hline Total & 80 & $100,0 \%$ & \\
\hline
\end{tabular}

Pada tabel yang di atas ada 66 orang mahasiswa (82,5\%) senang memposting berbagai konten di media sosial mereka, namun15 orang mahasiswa $(14,6 \%)$ menyatakan tidak suka memposting konten di media sosial mereka. Seperti pernyataan Khalda yang suka memposting kegiatannya, dari kegiatan harian dengan teman-teman sampai pada kegiatan liburan. Hal yang sama dengan Mochammad Deni Kurniawan, yang biasa dipanggil Deni, mahasiswa Pendidikan Jasmani Fakultas Ilmu Keolahragaan, Angkatan 2019, yang suka memposting konten olahraga karena dia sangat menyukai olah raga.

Tabel 4

Teman Di Media Sosial

\begin{tabular}{cccc}
\hline Declaration & Frequency & Percentage & Mean \\
\hline $4(\mathrm{SS})$ & 9 & $11,3 \%$ & \\
$3(\mathrm{~S})$ & 34 & $42,5 \%$ & \\
$2(\mathrm{KS})$ & 25 & $31,3 \%$ & 2,50 \\
$1(\mathrm{TS})$ & 12 & $15,0 \%$ & \\
\hline Total & 80 & $100,0 \%$ & \\
\hline
\end{tabular}

Tabel 4 menunjukkan 44 orang mahasiswa $(53,8 \%)$ setuju jika media sosial membantu mereka punya banyak teman baru, namun 37 orang mahasiswa lainnya $(46,3 \%)$ tidak setuju dengan media sosial menambah banyak teman. Menurut Shalsabilla media sosial tidak membuat temannya bertambah banyak karena follower di media sosial Shalsabilla adalah teman-teman yang biasa ketemu tatap muka seperti teman kuliah, selain itu akun media sosial Shalsabilla 
tidak bisa diakses sembarang orang karena di private, Shalsabilla merasa tidak nyaman jika follower tidak dikenal. Berbeda dengan Khalda yang mengatakan dengan media sosial bertambah teman baru.

\section{Ego}

Tabel 5

Ingin Dimengerti Di Media Sosial

\begin{tabular}{cccc}
\hline Declaration & Frequency & Percentage & Mean \\
\hline $4(\mathrm{SS})$ & 4 & $5,0 \%$ & \\
$3(\mathrm{~S})$ & 31 & $38,8 \%$ & \\
$2(\mathrm{KS})$ & 32 & $40,0 \%$ & 2,32 \\
1 (TS) & 13 & $16,3 \%$ & \\
\hline Total & 80 & $100,0 \%$ & \\
\hline
\end{tabular}

Berdasarkan table, 35 orang mahasiswa $(43,8 \%)$ berharap follower mereka mengerti mengenai diri mereka, namun 45 orang mahasiswa lainnya $(56,3 \%)$ tidak berharap follower mengerti keadaan mereka.

Tabel 6

Mengomentari Postingan Di Media Sosial

\begin{tabular}{cccc}
\hline Declaration & Frequency & Percentage & Mean \\
\hline $4(\mathrm{SS})$ & 3 & $3,8 \%$ & \\
$3(\mathrm{~S})$ & 27 & $33,8 \%$ & \\
$2(\mathrm{KS})$ & 39 & $48,8 \%$ & 2,27 \\
1 (TS) & 11 & $13,8 \%$ & \\
\hline Total & 80 & $100,0 \%$ & \\
\hline
\end{tabular}

Tabel 6 mengungkapkan bahwa terdapat rata-rata 50 orang mahasiswa $(62,6 \%)$ yang tidak suka mengomentari postingan orang lain di media sosial dengan alasan tidak mau timbul salah tafsir sehingga menjadi konflik, namun 30 orang mahasiswa $(37,5 \%)$ menyatakan bahwa mereka senang mengometari postingan orang lain,alasan mengometari postinga orang lain tidak akan membuat konflik. Salah seirang mahasiswa bernama Khalda menyatakan bahwa dia jarang mengomentari postingan orang lain, terutama pada postingan yang dia beri komentar, namun tidak ditanggapi, maka berikutnya Khalda tidak akan memberi feedback pada postingan berikutnya. Begitu pula pernyatan dari Mochammad Deni Kurniawan, tidak begitu sering mengomentari postingan orang lain, jika memberikan tanggapan atau komentar pada postingan teman tanggapannya hanya berupa candaan saja.

Tabel 7

Berpikir Panjang Di Media Sosial

\begin{tabular}{cccc}
\hline Declaration & Frequency & Percentage & Mean \\
\hline $4(\mathrm{SS})$ & 46 & $57,5 \%$ & \\
$3(\mathrm{~S})$ & 28 & $35,0 \%$ & \\
$2(\mathrm{KS})$ & 6 & $7,5 \%$ & 3,50 \\
1 (TS) & 0 & 0 & \\
\hline Total & 80 & $100,0 \%$ & \\
\hline
\end{tabular}


Tabel 7 menunjukkan bahwa sebagian besar mahasiswa UNJ yaitu 74 orang mahasiswa $(92,5 \%)$ menyatakan sebelum membuat postingan mereka akan berpikir panjang terlebih dahulu. atau berkirim pesan di media sosial, seperti yang diakui Khalda, sebelum ia memposting konten di media sosial, butuh waktu sekitar 5 menit sampai dengan 10 menit karena mengedit kontennya kembali, apakah sudah cukup bagus, sedangkan Shalsabilla mengatakan bahwa ia butuh waktu sekitar 1 - 3 menit berfikir sebelum memposting konten, sedangkan Khuri menyatakan bahwa butuh waktu sekitar sebulan untuk membuat sampai akhirnya memposting konten, alasanny merasa insecure tanggapan orang lain pada konten tersebut. Namun ada 6 orang mahasiswa $(7,5 \%)$ yang tidak berpikir panjang ketika ingin memposting konten di media sosial mereka.

Tabel 8

Menggunakan Logika Di Media Sosial

\begin{tabular}{cccc}
\hline Declaration & Frequency & Percentage & Mean \\
\hline $4(\mathrm{SS})$ & 15 & $18,8 \%$ & \\
$3(\mathrm{~S})$ & 15 & $18,8 \%$ & \\
$2(\mathrm{KS})$ & 20 & $25,0 \%$ & 2,65 \\
1 (TS) & 7 & $8,8 \%$ & \\
\hline Total & 80 & $100,0 \%$ & \\
\hline
\end{tabular}

Dengan tabel 8 menunjukkan ada 53 orang mahasiswa (66,25\%) yang menyatakan bahwa emosi harus dikendalikan dan mengutamakan logika, namun sisanya yaitu 27 orang mahasiswa $(33,75 \%)$ menyatakan emosi harus diutamakan dengan alasan dengan cara tersebut maka mereka bisa memahami maksud lawan bicara yang tidak bisa mereka lihat langsung secara fisik. Ketika melakukan interkasi kepada teman, baik secara di dunia nyata ataupun dunia maya melibatkan logika dan perasaan (emosi), namun di dunia maya sering tanpa disadari emosi sering tidak terkendali karena tidak bisa melihat langsung ekspresi dari lawan bicara, sehingga sengat mudah untuk terlibat konflik. Sebagian besar mahasiswa UNJ lebih senang menghindar terjadinya konflik, sehingga ketika mereka berinterkasi di media sosial maka emosi atau perasaan tidak diutamakan, namun logika yang lebih diutamakan.

\section{Superego}

Tabel 9

Terbawa Perasaan Di Media Sosial

\begin{tabular}{cccc}
\hline Declaration & Frequency & Percentage & Mean \\
\hline $44(\mathrm{SS})$ & 8 & $10,0 \%$ & \\
$3(\mathrm{~S})$ & 34 & $42,5 \%$ & \\
$2(\mathrm{KS})$ & 36 & $45,0 \%$ & 2,60 \\
$\begin{array}{c}1 \text { (Tidak } \\
\text { setuju) }\end{array}$ & 2 & $2,5 \%$ & \\
\hline Total & 80 & $100,0 \%$ & \\
\hline
\end{tabular}

Terdapat 42 orang mahasiswa (52,5\%) menyatakan terbawa perasaan jika ada postingan yang membawa perasaan seperti postingan kemanusiaan atau postingan mengenai bullying, 38 orang mahasiswa lainnya $(47,5 \%)$ menyatakan tidak gampang perasaannya tergugah. Seperti yang disampaikan oleh Khuri, mahasiswa UNJ dari Program Studi Bahasa Indonesia, Fakultas Bahasa dan Seni dari Angkatan 2019, yang tergugah perasaannya karena kasus bullying, dibawah ini pernyataan dari Khuri. 
"Waktu kasus nya Audrey yang anak kena bully sama temen temennya tapi ternyata cuma hoax. Saat sebelum tahu hoax, saya bener bener bela dia dengan hastag Justice for Audrey. Pokoknya saya bener bener terpengaruh sampe belain dia banget. Saya sampe ikut donasi yang kitabisa.com tuh yang cuma share ke wa bisa dapet 50k saya share terus. Tau taunya dia playing victim. Saya nyesel. Saya memperkaya orang salah"

Tabel 10

Menyampaikan Perasaan Ke Media Sosial

\begin{tabular}{cccc}
\hline Declaration & Frequency & Percentage & Mean \\
\hline $4(\mathrm{SS})$ & 2 & $2,5 \%$ & \\
$3(\mathrm{~S})$ & 25 & $31,3 \%$ & \\
$2(\mathrm{KS})$ & 40 & $50,0 \%$ & 2,20 \\
1 (TS) & 13 & $16,3 \%$ & \\
\hline Total & 80 & $100,0 \%$ & \\
\hline
\end{tabular}

Tabel 10 menunjukkan ada 27 orang mahasiswa (33,75\%) yang manyatakan bahwa melalui media sosial mereka menyampaikan ekspresi atau perasaannya. Namun 53 orang mahasiswa (66,25\%) tidak meenggunakan media sosial untuk menunjukan emosi atau perasaannya Namun bukan berarti mereka tidak pernah mengalami menyampaikan perasaan dengan follower mereka, seperti yang diceritakan oleh Khuri, mahasiswa UNJ dari Program Studi Bahasa Indonesia, Fakultas Bahasa dan Seni dari Angkatan 2019 sebagai berikut :

“...Pernah, jadi di twitter pernah berantem sama army fans nya boyband korea yang namanya BTS itu. Jadi ceritanya saya kan tidak suka sama tingkahnya army, terus saya sindir terus banyak army yang komen dan marah-marah sama postingan saya. Tapi saya tidak marah atau kesal membaca komenan itu, saya malah ketawa. Jadi rasanya puas gitu, karena meraka kan kebanyakan anak kecil gitu ya, dan seru aja ngeledekin anak kecil sampe marah marah gitu. Seperti ngeledekin anak kecil terus anak kecilnya nangis kan jadi seru gitu..."

Tabel 11

Berhenti Bermedia Sosial Ketika Emosi

\begin{tabular}{cccc}
\hline Declaration & Frequency & Percentage & Mean \\
\hline $4(\mathrm{SS})$ & 31 & $38,8 \%$ & \\
$3(\mathrm{~S})$ & 31 & $38,8 \%$ & \\
$2(\mathrm{KS})$ & 15 & $18,8 \%$ & 3,12 \\
$1(\mathrm{TS})$ & 3 & $3,8 \%$ & \\
\hline Total & 80 & $100,0 \%$ & \\
\hline
\end{tabular}

Melalui tabel yang ada diatas ada 62 orang mahasiswa (77,5\%) yang menyatakan mereka berhenti sejenak membuka media sosial ketika sedang emosi. Namun 18 orang mahasiswa $(22,5 \%)$ yang menyatakan bahwa mereka tetap mengakses media sosial ketika emosi. Salah satu mahasiswa bernama Salsabilla, mahasiswa UNJ, jurusan Bimbingan Konseling Fakultas Ilmu Pendidikan Angkatan 2019 adalah salah satu mahasiswa yang berhenti bermain media sosial ketika lagi emosi, seperti penyataannya berikut :

"saya butuh waktu sekitar mungkin 1-3 menit. Saya mikir dulu kalo saya posting tanggapan orang gimana, negatif ga nantinya atau ada yg tersinggung ga. Saya gamau mencari masalah di medsos apagi karena salah paham aja sebenernya" 


\section{Simpulan dan Saran}

Mahasiswa sebagai remaja masih mencari jati dirinya, ketika berinterkasi dengan orang lain seringkali mudah terpengaruh, ini bisa disebabkan oleh konsep diri yang masih berubahubah, salah satunya karena pengaruh lingkungan. Konsep diri dari mahasiswa UNJ ketika berinterkasi di luar dunia maya, sangat kuat, mereka mengakui tidak mudah terpengaruh oleh orang lain, hal sama juga terjadi di dunia maya, melalui interkasi di media sosial, mereka lebih suka menghindar konflik, tidak berkomentar negatif mengenai postingan orang lain, namun ternyata ada beberapa dari mahasiswa mudah terprofokasi oleh postingan orang lain. Oleh sebab itu mahasiswa sebagai remaja harus menyadari bahwa konsep diri mereka bisa berubah ketika berinterkasi di dunia maya, dengan berbagai sebab seperti tidak melihat langsung ekspresi lawan bicara.

\section{Daftar Pustaka}

Agustini, I. M. L. W. K., \& Arthana, I. K. R. (2016). Hubungan Konsep Diri dan Kecanduan Jejaring Sosial terhadap Prestasi Akademik pada Mahasiswa Jurusan Pendidikan Teknik Informatika. Kumpulan Artikel Mahasiswa Pendidikan Teknik Informatika (KARMAPATI), 5(1), 1-7.

Amalia, R. F. dan D. (2019). Mengungkap Komunikasi Kelompok Belajar : Peran Pola Komunikasi dalam Membangun Kesadaran tentang Kekerasan Seksual pada Anak Jalanan. Jurnal The Messenger, 53(9), 1689-1699. https://doi.org/10.1017/CBO9781107415324.004

Ayun, P. Q. (2015). Fenomena Remaja Menggunakan Media Sosial dalam Membentuk Identitas. KOMUNIKA: Jurnal Dakwah Dan Komunikasi, 11(2), 184-197. https://doi.org/10.24090/komunika.v11i2.1365

Ayutiani, D. N., \& Satria Putri, B. P. (2018). Penggunaan Akun Instagram Sebagai Media Informasi Wisata Kuliner. PRofesi Humas: Jurnal Ilmiah Ilmu Hubungan Masyarakat, 3(1), 39. https://doi.org/10.24198/prh.v3i1.11683

Bulan Cahya Sakti, M. Y. (2013). Penggunaan Media Sosial Instagram Dalam Pembentukan Identitas Diri Remaja. Interaksi-Online, 12(2), 1-12. Retrieved from https://ejournal3.undip.ac.id/index.php/interaksionline/article/download/21950/20197

Diah, S. R. (2018). Berapa Lama Orang Indonesia Menggunakan Internet Dalam Sehari? https://ekonomi.kompas.com/read/2018/02/19/184500826/berapa-lama-rata-rataorang-indonesia-gunakan-internet-dalam-sehari

Felita, P., Siahaja, C., Wijaya, V., Melisa, G., Chandra, M., \& Dahesihsari, R. (2016). Pemakaian Media Sosial Dan Self Concept Pada Remaja. Jurnal Ilmiah Psikologi MANASA, 5(1), 30-41.

George Rizer, D. J. G. (2004). Teori Sosiologi Modern. Kencana Prenada Media Group.

Gibson, J. L. (1994). Organisasi: Perilaku, Struktur, Proses. Penerbit Erlangga.

Hayati, L. (2018). Konsep Diri Anak-anak Pengguna Aktif Media Sosial. Society, 6(2), 58-64. https://doi.org/10.33019/society.v6i2.65

Hogan, M., \& Strasburger, V. C. (2018). Social Media and New Technology: A Primer. Clinical Pediatrics, 57(10), 1204-1215. https://doi.org/10.1177/0009922818769424

Ivon Baharani. (2016). Pengaruh Konsep Diri dan Interaksi Antar Pengguna terhadap Kreativitas Produksi Video Dubsmash Pengguna Instagram. Universitas Diponegoro Semarang.

Karmila, R. (2018). Media Kajian Kewarganegaraan perempuan melalui pendidikan politik. Jurnal Civics: Media Kajian Kewarganegaraan Vol., 15(1), 120-125.

Katadata.com. (2018). Pengguna Internet Masih Terkonsentrasi di Jawa. https://databoks.katadata.co.id/datapublish/2018/02/22/pengguna-internet-indonesiamasih-terkonsentrasi-di-jawa

Malhotra, N. K. (2010). Marketing Research sixth edition An Applied Orientation. New Jersey: Prentice Hall.

Moleong, L. J. (2006). Metodologi Penelitian Kualitatif. Remaja Rosdakarya. 
Mulawarman, M., \& Nurfitri, A. D. (2017). Perilaku Pengguna Media Sosial beserta Implikasinya Ditinjau dari Perspektif Psikologi Sosial Terapan. Buletin Psikologi, 25(1), 36-44. https://doi.org/10.22146/buletinpsikologi.22759

Rahmat, J. (1999). Psikologi Komunikasi. Remaja Rosdakarya.

Rizadan, M. (2019). Media Sosial Instagram Sebagai Alat Pembentuk Citra Diri Pada Mahasiswa. Universitas Sriwijaya.

Stevens, R., Gilliard-Matthews, S., Dunaev, J., Woods, M. K., \& Brawner, B. M. (2017). The digital hood: Social media use among youth in disadvantaged neighborhoods. New Media and Society, 19(6), 950-967. https://doi.org/10.1177/1461444815625941

Tribunnews.com. (2016). Mayoritas Pengguna Aktif Instagram di Indonesia Adalah Anak Muda Artikel ini telah tayang di Tribunnews.com dengan judul Mayoritas Pengguna Aktif Instagram di Indonesia Adalah Anak Muda. https://www.tribunnews.com/techno/2016/01/15/mayoritas-pengguna-aktifinstagram-di-indonesia-adalah-anak-muda

Weinstein, E. (2018). The social media see-saw: Positive and negative influences on adolescents' affective well-being. New Media and Society, 20(10), 3597-3623. https://doi.org/10.1177/1461444818755634

Yuniati, Y., Yuningsih, A., \& Nurahmawati, N. (2015). Konsep Diri Remaja dalam Komunikasi Sosial melalui "Smartphone." MIMBAR, Jurnal Sosial Dan Pembangunan, 31(2), 439. https://doi.org/10.29313/mimbar.v31i2.1552 